\title{
Influence of Land Cover Changes and Climatic Variability on Discharge Regime of Njoro River Catchment in Kenya
}

\author{
Kennedy Kitonga Mwetu \\ Department of Agricultural and Biosystems Engineering, Kenyatta University, Nairobi, Kenya \\ Email: mwetu.kennedy@ku.ac.ke,kmwetu@yahoo.com
}

How to cite this paper: Mwetu, K.K. (2019) Influence of Land Cover Changes and Climatic Variability on Discharge Regime of Njoro River Catchment in Kenya. Open Access Library Journal, 6: e5461.

https://doi.org/10.4236/oalib.1105461

Received: May 10, 2019

Accepted: July 7, 2019

Published: July 10, 2019

Copyright $\odot 2019$ by author(s) and Open Access Library Inc.

This work is licensed under the Creative Commons Attribution International License (CC BY 4.0).

http://creativecommons.org/licenses/by/4.0/

\section{c) (7) Open Access}

\begin{abstract}
This study analyzed influence of land cover changes and climatic variability from 1973 to 2000 on discharge regime of Njoro River Catchment in Kenya. Analysis focused on hydro-meteorological data of 1977-1984 (Period I) and 1992-2000 (Period II), which are the periods found with available data and Landsat imageries for the same periods. Results show a downward trend of annual discharge that corresponded to increased deforestation. Forest area decreased by $25 \%$ while open fields combined with grasslands increased by $58 \%$ between the two periods. Discharge in Period I was $36 \%\left(0.23 \mathrm{~m}^{3} / \mathrm{s}\right.$ or 82 $\mathrm{mm} / \mathrm{a}$ ) higher than Period II whereas increase of annual temperature $\left(0.75^{\circ} \mathrm{C}\right)$ between the two periods was significant $(\mathrm{P}<0.05)$ but decrease in rainfall $(24.87 \mathrm{~mm} / \mathrm{a})$ was not significant with effect of $25 \%$ deforestation. Statistical analysis of both four rainy and four dry years in the two periods showed that: 1) mean monthly discharge in Period I was not different $(\mathrm{P}<$ 0.05 ) and variability in decreases was higher (z-score: $4.60>3.98$ ) in rainy years compared to dry years, and 2) mean discharge in Period II was different $(\mathrm{P}<0.05)$ and variability in decreases was higher again in rainy years than dry years (z-score: $4.78>4.77$ ). Influence of climatic variability alone accounted for $25 \%\left(0.06 \mathrm{~m}^{3} / \mathrm{s}\right)$ on reduction of discharge while human activity mainly deforestation accounted for $75 \%\left(0.17 \mathrm{~m}^{3} / \mathrm{s}\right)$ on reduction of discharge in Period II. This implies that land cover changes were largely responsible for decrease in discharge and therefore, intervention measures of restoring forest cover are recommended for Njoro River Catchment.
\end{abstract}

\section{Subject Areas}

Agricultural Science, Ecology, Environmental Sciences

\section{Keywords}

Climatic Variability, Deforestation, Discharge Regime, Njoro River 


\section{Introduction}

Modifications in the long-term discharge of a river can be caused by several factors including climatic variability, changes in land use and land cover in the upstream basin, construction of large artificial lakes and diversion of water for irrigation. Among these, the two most likely drivers of long-term discharge modifications are variability in precipitation and changes in land use in the upstream basin [1]. Depending on the amount of rainfall and the degree of surface disturbance in humid tropics, removal of natural forest may result in a considerable increase in water yield, as well as a decline in discharge with time under reforestation [2]. Nonetheless, similar findings could not be reached by studies on mesoor large-scale tropical basins that have a variety of land use classes, and vegetation in various stages of regeneration [3].

A change in streamflow is a function of both climate and human activities with the latter accounting for over two-thirds in a recent study that used rainfall-runoff relationship in conjunction with statistics [4]. In addition, a shift from sub-surface flow to overland storm flows that often accompanies deforestation followed by adverse land use can lead to dramatic changes in the catchment peak flows [5]. Furthermore, vegetation removal, which reduces evapotranspiration, can cause increased overland flow and groundwater inputs into the stream [6]. A shift in flow regime may be expected with increased peaks during the rainy season and lowered flows in the dry season if the change in infiltration associated with land use change overrides the effects of reduced evapotranspiration [2]. Accordingly, land use and or land cover plays a crucial role in driving hydrological processes within watersheds.

Complex and tedious task of generating land cover information in spatial and temporal domain, has been made easy by utilization of remotely sensed images in Geographic Information System (GIS) environment [7]. The need for land cover change detection and quantification at larger scale makes satellite imagery most cost effective, efficient and reliable source of data. Such reliable data on recent changes in land cover dynamics can facilitate synoptic analyses of earth-system function, patterning and changes at local, regional or global scales over time [8]. Due to increasing changes in land use mainly by human-induced activities, detection and quantification of land cover dynamics through the integration of remote sensing and GIS is inevitable to ensure sound watershed management. Planners need to understand how land use change influences the catchment hydrology so as to formulate policies that minimize undesirable effects of future land use changes.

There has been a rapid conversion of indigenous forests to small-scale agricultural farms during the last three decades in Njoro River Catchment (NRC). 
Changes in land cover increase impervious ground surfaces, decrease infiltration rate and increase runoff, hence causing low baseflow during dry seasons. Also high population growth and immigration in the catchment, may have further contributed to land degradation, especially on steep slopes and interfered particularly with wildlife in the receiving Lake Nakuru. Major environmental changes such as a decline in groundwater table, increase in surface runoff, reduction in baseflow in dry periods may be associated with high temperatures being experienced. Nonetheless, hydrological response to these land cover transformations within the catchment has not been determined. As a result, this study was undertaken to evaluate the influence of these changes on Njoro River discharge regime. Specific objectives of the study were to: 1) quantify spatial-temporal land cover dynamics from 1970 to $2000 ; 2$ ) establish trends in discharge, temperature and rainfall over the same period and; 3 ) determine response of river discharge to land cover changes and climatic variability.

\section{Description of Study Area}

Figure 1 shows Njoro River Catchment (Latitude $0^{\circ} 18^{\prime}$ to $0^{\circ} 23^{\prime}$ South and Longitude $35^{\circ} 53^{\prime}$ to $35^{\circ} 58^{\prime}$ East), which is part of Mau Escarpment in western rim of East African Rift Valley in Kenya [9]. Its annual rainfall range from $1011 \mathrm{~mm} / \mathrm{a}$ to $1055 \mathrm{~mm} / \mathrm{a}$ and follow a trimodal pattern with highest peak in April linked to Inter-Tropical Convergence Zone (ITCZ) while temperature vary from $9^{\circ} \mathrm{C}$ to $28^{\circ} \mathrm{C}$ [10]. The catchment is characterized by two wet periods in May-September and November-December and a dry period in January-April but there are huge seasonal, as well as inter-annual variations in rainfall [11]. The geologic formations of rocks and soils are influenced by volcanic nature that occupies larger part of Rift Valley [12]. Upland areas, which are forested consisting of tertiary soils developed from ashes and other pyroclastic rocks of recent volcanoes while lower reaches are composed of erosive lacustrine soils [9]. The topography is predominantly rolling land with slopes ranging from $2 \%$ in the plains to $54 \%$ in the hills [13].

The catchment is drained by Njoro River $(60 \mathrm{~km})$, which descends from 2800 $\mathrm{m}$ above mean sea level (amsl) at its source in Mau Hills to about $1700 \mathrm{~m}$ amsl at its mouth in Lake Nakuru. It also encloses a contributing surface area of about $280 \mathrm{~km}^{2}$ [14]. The river has one main tributary (Little Shuru) and meanders through forest and agricultural lands before serving several urban settlements [13]. The lake provides habitat for many species, such as flamingos and Black Rhino among others [9]. Since 1990 the lake was designated as a Ramsar wetland of international importance. However, the lake is under great pressure of degradation mainly as a result of siltation and fluctuations of water level. The cause of this has not yet been found certainly but recent studies have linked it to main social economic activities in the catchment, mainly large scale conversion of forest lands into agricultural farms, overgrazing and rapid development of urban centers [13] [15]. 


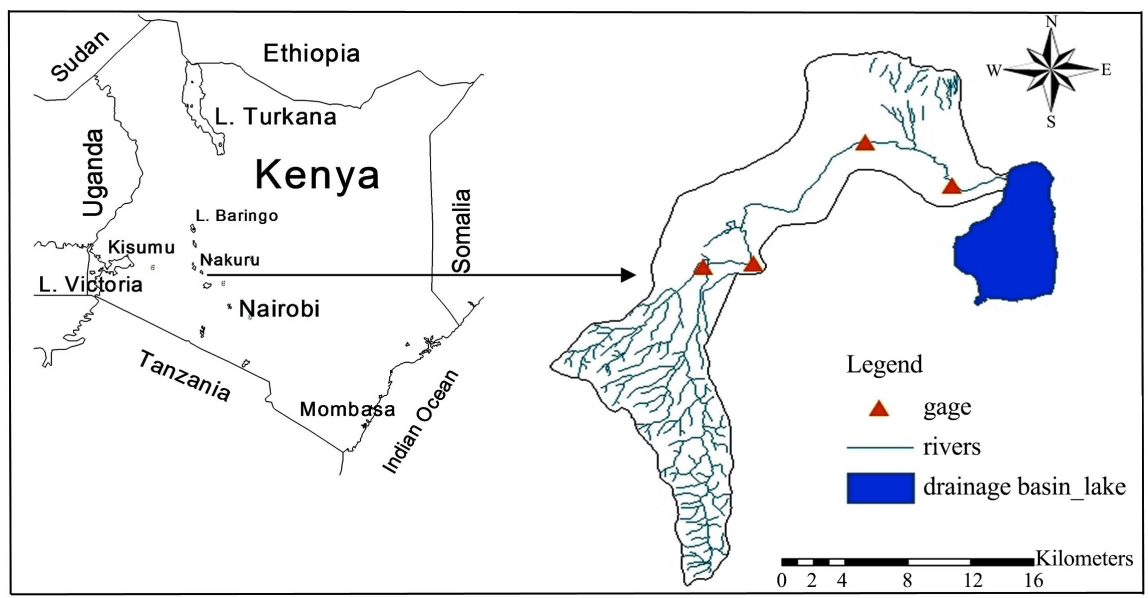

Figure 1. Map of study area showing expanded Njoro River catchment in Kenya.

\section{Methodology}

\subsection{Geographic Information System Data}

Three topographic map sheets coded 118.4, 119.3 and 132.2 with a scale of 1:50,000 from Kenya Survey Institute were scanned and utilized in generation of GIS database. The maps covered the entire catchment and were mosaicked using ArcGIS 9.2 software. The mosaicked map was projected to local coordinate system (UTM-zone 36M, datum-Arc 1960 and spheroid Clarke 1880) and used as master map in georeferencing of acquired Landsat images. Table 1 demonstrates characteristics of Landsat imageries used in the classification of land cover. A 90 $\mathrm{m}$ digital elevation model (DEM) from Shuttle Radar Topographic Mission (SRTM) was processed and used to clip the catchment boundary.

\subsection{Land Cover Classification and Its Accuracy Assessment}

Land cover and land use types of NRC were determined from Landsat images of 1973, 1986 and 2000. The selected images had zero percentage of cloud cover and a reasonable spatial resolution appropriate for analysis of sub-regional land cover [10] [16]. Moreover, the images coincided with period thought of as significant under which great land cover change occurred. Distinction in reflectance between forested and non-forested areas is normally greatest during dry season. This is because there is reduction in confusion at forest edges between dense forest and small-scale agricultural farms [17] [18]. Consequently, the images corresponding to dry season period (January and February) were selected since this usually occurs between harvesting and planting time. During this period farmers leave their farms fallow, water becomes scarce and nothing is put into degraded lands. This minimizes the effects of undergrowth reflectance that usually mimic forest spectral signature during wet season, a typical problem of land cover classification in tropical regions [13].

Finally, the images were imported into Integrated Land and Water Information System (ILWIS), software via geo-gateway command and a new map list 
Table 1. Characteristics of Landsat imageries used in land cover classification.

\begin{tabular}{lcccc}
\hline Acquisition date & Sensor & Cloud cover (\%) & Path/row & Resolution \\
\hline 31 January, 1973 & Landsat 4 MSS & 0.00 & $169 / 60$ & $57 \times 57$ \\
28 January, 1986 & Landsat 5 TM & 0.00 & $169 / 60$ & $30 \times 30$ \\
27 January, 2000 & Landsat 7 ETM+ & 0.00 & $169 / 60$ & $28.5 \times 28.5$ \\
\hline
\end{tabular}

was created by combing all bands with same resolution. The image classification was based on a stepwise process using supervised maximum-likelihood classification. In the first step, the images were visually enhanced by creating false colour composite in map list operation. Then, the map list was geometrically corrected using tie points clipped from the mosaicked toposheets. Resulting raster map was re-sampled by nearest neighbour method using corners to correct North orientation. Based on main land use patterns, five land-cover domains were identified as relevant for fully classifying land cover types. As a final stage, the Global Positioning System (GPS) data layer was crossed with land cover map classified of the year 2000, to assess accuracy level. Extraction of the catchment boundary and area from the classified image was accomplished by inside clipping with automatically generated DEM outline.

\subsection{Acquisition of Hydro-Meteorological Data}

Meteorological data was available for six rainfall stations within the catchment and one discharge station (2FC05) at the middle reaches of Njoro River near Egerton University (Figure 1). With the exception of Egerton and Njoro Plant Breeding Stations (NPBS) among the rainfall stations, all other stations had records less than 23 years in length, and consequently they were abandoned in this study. Egerton station data was used and it was preferably good since it represented the upper catchment area, which was affected by massive land cover changes. In addition, this station had sunshine data that could allow computation of potential evapotranspiration (ETo). Presence of gaps in data usually reveals doubt in quality level and emphasizes need to undertake data quality analysis [9]. Three types of data quality tests were applied on the acquired data, namely: 1) double mass curve; 2) ETo comparison with previous studies and; 3) quality analysis of inter-annual variability [1].

Double mass curve (DMC) technique was adopted to test rainfall and streamflow records for nonhomogeneity and inconsistency. This technique usually shows period of changing trends and specifically point at which the record deviates from the trend, indicating inconsistency of the data [19]. A change in gradient or breaks in the trend line means that the data is not good and correction has to be applied. ETo was calculated for period 1977-1993 using modified Penman Monteith equation [20] in Cropwat version 4.3 software. Computation could not be extended beyond the year 1993 since sunshine data was not available at Egerton weather station. 


\subsection{Determination of Discharge Influence Due to Land Cover Changes and Climatic Variability}

To clarify mechanisms driving discharge variability in NRC, study period (24 years) was divided into two and each was examined for time series analysis of long-term mean of rainfall, discharge and temperature. First period I (1977-1984) had little changes while second period II (1992-2000) had intense changes in land cover. The time interval 1985-1991 was discarded to allow for recognizable difference in land cover between the two periods. These periods were long enough to include a representative sample of climatic variability and considerable land cover change. The variation of mean annual discharge in terms of distribution and magnitude was analyzed and compared between the periods. Influence of land cover changes was examined by determining variability of discharge in rainy and high flow seasons. To understand the influence of land cover changes on discharge, we tested hypothesis that land cover changes between the periods does not affect mean discharge. This was done through analyzing differences in means of rainfall and discharge in rainy and high flow seasons.

Main components of surface hydrology (rainfall, discharge and evapotranspiration) were subjected to statistical analysis of T-test and Z-test to check their variability and dynamics due to changes of land cover and climatic variability. T-test statistic determined the difference in discharge means between the two periods relative to spread or variability of their scores. The formula for the T-test is a ratio. The top part of the ratio is just difference between the two means or averages. The bottom part is a measure of variability or dispersion of the scores. The following formulae were found relevant in this study [1] as follows:

$$
t=\frac{\bar{x}_{1}-\bar{x}_{2}-D}{\sqrt{\frac{S_{1}^{2}}{n_{1}}}+\frac{S_{2}^{2}}{n_{2}}}
$$

where $\bar{x}_{1}$ and $\bar{x}_{2}$ are means of the two periods, $D$ is hypothesized difference between the periods mean (Ho or null hypothesis was that means for the two periods are equal), $S_{1}$ and $S_{2}$ are standard deviations of the two periods, and $n_{1}$ and $n_{2}$ are sizes of the two periods (in months/years). Degrees of freedom for the two periods were $n_{1}-1$ and $n_{2}-1$ respectively. The z-test formula is given by;

$$
z=\frac{\bar{x}_{1}-\bar{x}_{2}-D}{\sqrt{\frac{\sigma_{1}^{2}}{n_{1}}+\frac{\sigma_{2}^{2}}{n_{2}}}}
$$

where $\sigma_{1}^{2}$ and $\sigma_{2}^{2}$ are variance for the two periods calculated as $\frac{\sum\left(x_{1}-\bar{x}_{1}\right)^{2}}{n_{1}}$ and $\frac{\sum\left(x_{2}-\bar{x}_{2}\right)^{2}}{n_{2}}$ respectively. Null hypothesis (Ho) was means of the two periods were not different. Water balance for a catchment can be estimated as [4]:

$$
P=E+Q+\Delta S
$$


where $P$ is rainfall, $E$ is evapotranspiration, $Q$ is discharge, and $\Delta S$ is change in catchment water storage. For a long period of time say over 10 years, $\Delta S$ is assumed zero. Hence long-term average evapotranspiration can be estimated as follows [21]:

$$
\frac{E}{P}=\frac{1+w\left(E_{0} / P\right)}{1+w\left(E_{0} / P\right)+\left(E_{0} / P\right)^{-1}}
$$

where $E_{0}$ is potential evapotranspiration, and $w$ is a modal parameter relating to vegetation type and was set 0.50 in this study. Change in annual discharge was estimated as follows;

$$
\Delta Q^{\mathrm{clim}}=\beta \Delta P+\gamma \Delta E_{0}
$$

where $\Delta Q^{\text {clim }}, \Delta P$ and $\Delta E_{0}$ are changes in annual discharge due to climatic variability, rainfall and potential evapotranspiration respectively [22]. $\beta$ and $\gamma$ are sensitivity of discharge to rainfall and potential evapotranspiration respectively. The sensitivity coefficients are estimated as:

$$
\begin{gathered}
\beta=\frac{1+2 x+3 w x}{\left(1+x+w x^{2}\right)^{2}} \\
\gamma=-\frac{1+2 w x}{\left(1+x+w x^{2}\right)^{2}}
\end{gathered}
$$

where $x$ is index of dryness and is equal to $\left(E_{0} / P\right)$.

\section{Results and Discussion}

\subsection{Spatial-Temporal Land Cover Changes}

Figure 2 shows thematic maps derived from satellite images of 1973, 1986 and 2000 while their areal coverage are demonstrated in Table 2. An initial comparison of these maps shows a decrease in forest area throughout the time scale analyzed. Again, the forest area in 1973 had clear outline, which indicated a thick forest without deforestation. In 1986 some forest had been cleared and clear patches or portions were visible within the forest area. Finally, in 2000 much of the forest had been cut and only steep slopes at the top most area had thick forest cover remaining.

Table 2. Statistics of areal land cover changes in Njoro River catchment in 1973-2000 in $\mathrm{km}^{2}$.

\begin{tabular}{ccccccc}
\hline Land use & 1973 & 1986 & 2000 & $1973-1986$ & $1986-2000$ & $1973-2000$ \\
\hline Cleared & 22.48 & 58.72 & 37.44 & +36.24 & -21.28 & +14.96 \\
Farms & 87.98 & 73.19 & 74.20 & -14.79 & +1.01 & -13.78 \\
Forest & 117.21 & 101.58 & 88.03 & -15.63 & -13.55 & -29.18 \\
Grass & 51.94 & 46.45 & 80.28 & -5.49 & +33.83 & +28.34 \\
Water & 0.39 & 0.06 & 0.06 & -0.33 & 0.00 & -0.33 \\
\hline
\end{tabular}




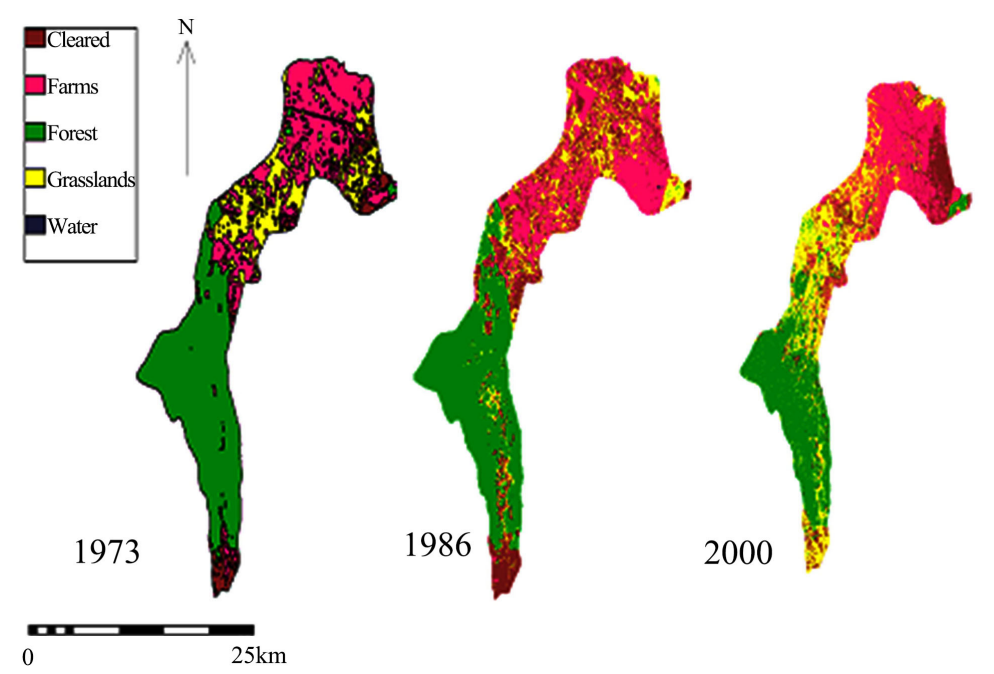

Figure 2. Land cover maps of Njoro River catchment for 1973, 1986 and 2000 processed from Landsat imageries.

Table 2 demonstrates statistics of areal land cover changes. It is demonstrated that cleared fields increased by about $36 \mathrm{~km}^{2}$ (161\%) from 1973 to 1986, and later decreased by about $21 \mathrm{~km}^{2}$ (36\%) between 1986 and 2000. This reflected a situation that was very common in the area, when residents could cut down large parts of forest for commercial timber or charcoal production and thereafter leave the area to regenerate itself. In general, the open fields increased by about $15 \mathrm{~km}^{2}$ (67\%) from 1973 to 2000 that is a significant land cover change. Farms seemed to have decreased by about $15 \mathrm{~km}^{2}$ (17\%) between 1973 and 1986, which is not realistic given that no people moved out of the catchment. The possibility here is that, probably some pixels representing farms were included in cleared and grassland classes during computation since the images of dry season were used. Grasslands decreased by about $6 \mathrm{~km}^{2}(11 \%)$ in period 1973 to 1986 and increased by about $34 \mathrm{~km}^{2}$ (73\%) from 1986 to 2000 . This coincides with practice of small-scale farmers, who clear the forest for agriculture and leave it fallow after some years to use it for grazing. Overall, the grasslands increased by about 28 $\mathrm{km}^{2}$ (55\%) from 1973 to 2000 . This is consistent with gradual forest cover conversion to grasslands in the catchment throughout the period of study.

Area coverage for water from the maps pursued a declining trend with time. This is not true and it could have occurred since most of water pixels seemed to have been omitted in water class, and included in other dormant classes. This omission and inclusion errors further attributed to low image classification accuracy (62.3\%). similarly, other studies in the tropics have found a similar problem on image accuracy assessment [13] [23]. Forest cover decreased by about $29 \mathrm{~km}^{2}$ (25\%) from 1973 to 2000 . This is a big land cover change given that Njoro catchment is only about $280 \mathrm{~km}^{2}$. Studies have shown that increases in catchment's proportion of open surface to $>10 \%$ may significantly impact stream hydrology [24]. Hydrological effects of increased open surface typically result in elevated quick flow generation and produce both high magnitudes and early peaks in 
storm hydrographs [25]. Alteration of a catchment can have dramatic effects on hydrological processes within stream ecosystems [26]. On basis of decline on this vegetation cover, the study investigated its influence on discharge for a period of 24 years on a typical low order stream.

\subsection{Accuracy Assessment for Landsat Imagery Classification}

Accuracy assessment of image classification cannot be undermined when using Landsat imagery to develop land cover maps [27]. This is because the whole task of assigning each pixel to a class is based on pattern recognition and sometimes the images are distorted. Atmospheric conditions, illumination, noise from sensors and classes with mixed spectral properties due to composites of land covers, greatly affects quality of the image. The assessment involved comparison of a sample of the map data with actual ground conditions, and a confusion matrix was generated. Table 3 demonstrates classification accuracy assessment for Landsat 2000.

In overall, image classification accuracy of $63.2 \%$ was obtained. This value was an improvement from a previous record of $58 \%$ for the same region [13]. This low percentage of classification accuracy could be attributed to time difference between image acquisition and collection of reference data. Similarly, the image used was that of $27^{\text {th }}$ January 2000 while ground control data were collected in the field in 2006. Therefore, low accuracy could be linked to seasonal variation from 2000 to 2006. However, thematic maps derived were sufficient to assess decadal land cover changes. Water class had very small area coverage and displayed no value in confusion matrix. Likewise, grasslands were difficult to classify since many of its reference data were excluded from "grassland" class, thus area in the classified image was probably underestimated. On the other hand, forest and farms in the image were not very reliable as many reference data of other classes were included in them. Thus, their areas in classified image were probably overestimated.

\subsection{Linking Land Cover and Climate Variability to Discharge Regime}

\subsubsection{Analysis of Data Quality}

Based on recommendation of World Meteorological Organization [28], minimum rain gauge density for this area of study should vary from 100 to 250 $\mathrm{km}^{2} /$ gauge, or equivalently 1 to 3 stations. However, this represents applicable minimum requirement and does not factor in certain storm types and site specific conditions. Therefore, the catchment has been installed with six rain gauge stations. However, only Egerton and Njoro plant breeding stations (NPBS) were used because had data for long period of time. The records from these stations were used after scrutinizing them using DMC technique. Figure 3 shows DMC with NPBS record as base station. The assumption was made that NPBS record was homogenous and independent from the rest after examining its topography and nature of data coverage. 


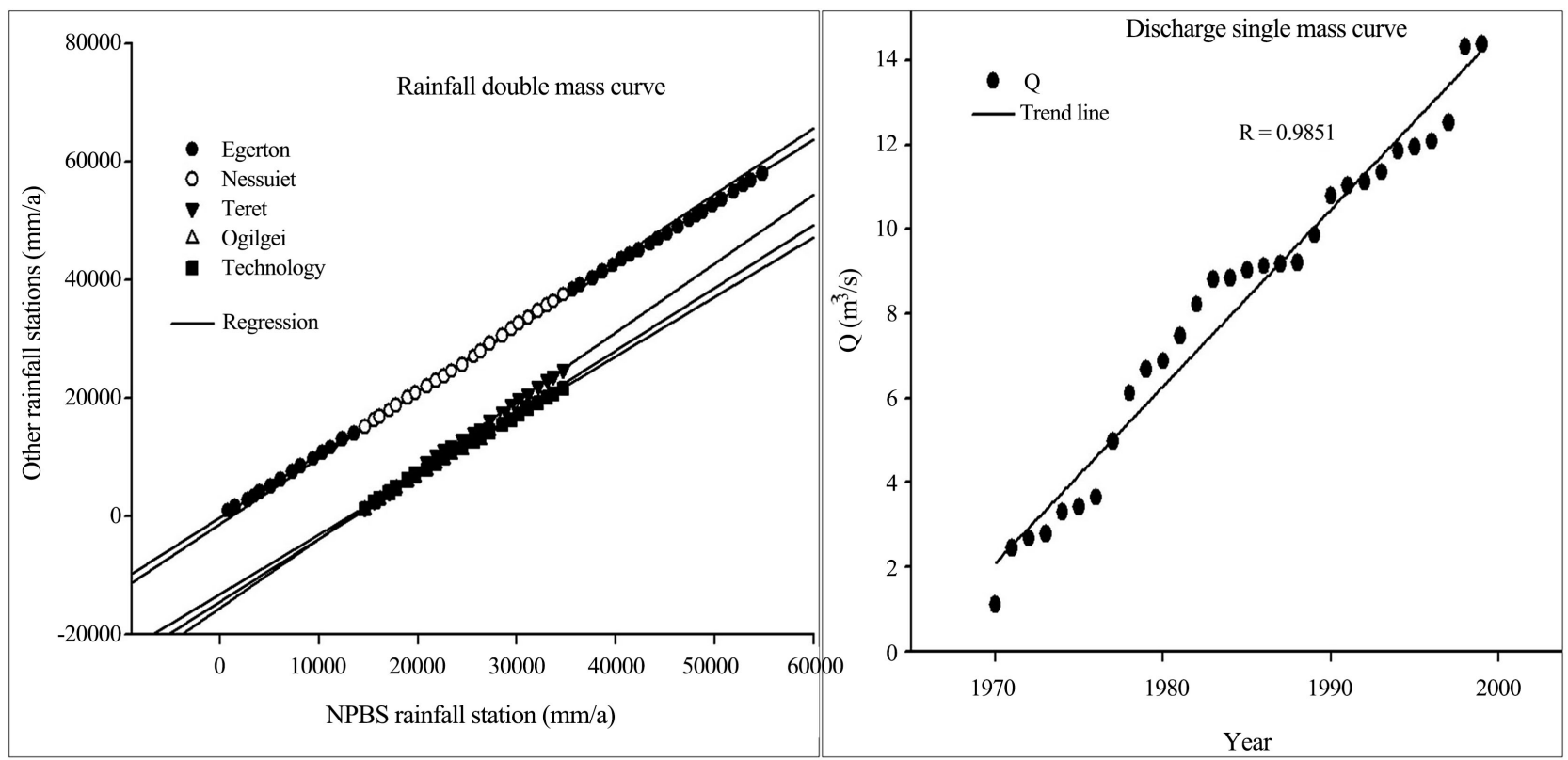

Figure 3. Output of double mass curves for rainfall stations and mean annual discharge.

Table 3. Classification accuracy assessment for Enhanced Landsat imagery of 2000.

\begin{tabular}{ccccccc}
\hline & \multicolumn{5}{c}{ Reference data } \\
\hline Forest & Water & Cleared & Farms & Grass & Accuracy \\
\hline Water & 252 & 0 & 6 & 49 & 15 & 0.78 \\
Cleared & 0 & 0 & 0 & 0 & 0 & 0.00 \\
Farms & 110 & 0 & 382 & 121 & 33 & 0.67 \\
Grass & 56 & 0 & 18 & 433 & 154 & 0.61 \\
Reliability & 0.56 & 0.00 & 0.85 & 0.49 & 0.72 & 63.20 \\
\hline
\end{tabular}

Overall accuracy $=(252+0+382+433+525) / 2519=0.632 \times 100=63.20 \%$.

Table 4 demonstrates parameters of rainfall Double Mass Curve for Njoro River catchment. Correlation analysis shows that all rainfall stations had straight trend lines without breaks implying consistent and homogenous data. The statistical analysis yielded a correlation coefficient $\left(R^{2}\right)$ close to one further confirming good quality data. In addition, this analysis revealed that Teret rainfall station with slope gradient of +1.1654 located on highest elevation received highest average annual rainfall. Again, annual mean ETo for the same period (24 years) was computed by subtracting mean annual discharge $\left(161.18 \mathrm{~mm} / \mathrm{a}\right.$ over $90 \mathrm{~km}^{2}$, which is the area of upper Njoro River catchment) from average annual rainfall data from Egerton station $(1036.23 \mathrm{~mm} / \mathrm{a})$. In this case CropWat estimates using Modified Penman Monteith equation were dropped due to lack of sunshine data. The resulting ETo $(875.05 \mathrm{~mm} / \mathrm{a}$ or $2.4 \mathrm{~mm} / \mathrm{d})$ was in order with estimates of 
$1095 \mathrm{~mm} / \mathrm{a}$ or $3 \mathrm{~mm} / \mathrm{d}$ obtained by another study [15]. Finally, analysis of data quality using interannual variability of rainfall record is shown on Figure 6. Annual ETo was plotted against annual rainfall. The dependence of annual ETo on annual rainfall reveals a characteristic of water stressed region [2]. Likewise, if an important biases existed in rainfall data such dependence could not have been found. These three tests confirmed that rainfall data were of acceptable quality.

Similar approach was applied to discharge data but a single mass curve method was used since only one data set was available. Figure 3 shows this result, which depicts a straight regression line with correlation of $98.51 \%$, again confirming a good quality data. To sum up, both data sets (rainfall and discharge) revealed that were of good quality for use in analyzing influence of land cover changes and climate variability on discharge regime in Njoro River catchment.

\subsubsection{Analysis of Hydro-Meteorological Data}

Figure 4 shows plots of monthly rainfall distribution indicating a trimodal pattern with peaks in April, August and November. The peak in April was highest and is linked with ITCZ, which brings long rains in East Africa [29].

Table 4. Parameters of rainfall Double Mass Curves in Njoro river catchment.

\begin{tabular}{cccc}
\hline Rainfall station & Length (years) & DMC gradients & Correlation \\
\hline Egerton & 58 & +1.0675 & 0.9997 \\
Nessuiet & 23 & +1.1156 & 0.9993 \\
Terret & 23 & +1.1654 & 0.9992 \\
NPBS & 23 & +1.0064 & 0.9996 \\
Ogilgei & 18 & +1.0628 & 0.9977 \\
\hline
\end{tabular}

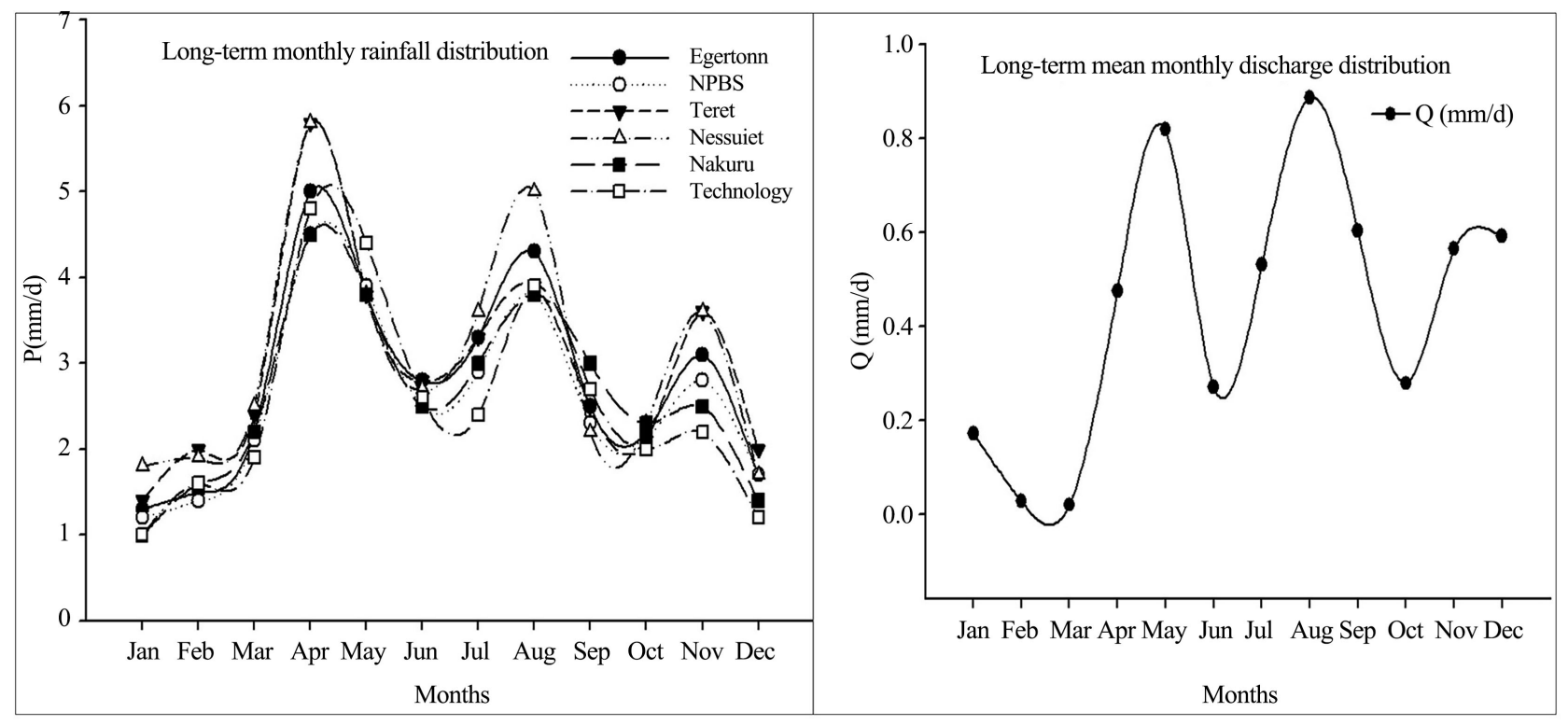

Figure 4. Graphs for monthly rainfall and hydrograph for Njoro River from 1970 to 2000. 
In Figure 4, hydrograph follows a similar trimodal pattern of the rainfall. However, April rainfall peak was one month lag in mean monthly discharge distribution. Such a response can be linked to a soil moisture deficit. In this case, it seems most of stormwater was used to overcome initial abstraction of the soil matrix before generating both overland and groundwater flows to the river. To expound on this, other factors influencing discharge other than rainfall were investigated. In Figure 5, it is shown that discharge trend decreased more than that of rainfall in the same period (1970-2000). It was also observed that, discharge strongly depended on annual rainfall events, meaning possibility of groundwater recharge in the catchment was in doubt. Additionally, starting from 1990 discharge trend declined further with exception of rainfall extreme years (1994, 1997 and 1998). This coincided with the period associated with highest land cover change and could be argued that, change in land cover was a feasible contributing factor in the catchment.

Figure 6 shows annual time series of evapotranspiration and rainfall in 1977-1993. Another observation from the study was that, greatest part of the catchment has tertiary soils composting of black ashes and welded tuffs [30]. Such permeable soils encourage infiltration and downward percolation [15]. Interflow from rainfall events were expected to be greater in quantity than overland flow to end up in streams as baseflow and to some extent recharge groundwater. Surprisingly, the river and groundwater sources are drying up faster in period II. It could be argued that, higher surface albedo from deforestation, reduced leaf area index and shallow rooting depth of grass all reduced evapotranspiration. Grass leaves earned less litter on the ground surface and capacity of surface retention was greatly reduced. Consequently, greater proportion of stormwater turned to be instantaneous overland flow to the streams. This explained why correlation between mean monthly rainfall and discharge in period II had no significant relationship $\left(\mathrm{R}^{2}=0.01\right)$. This finding was in agreement with results from other studies [9] [15].

Potential evapotranspiration was found to range from $1300 \mathrm{~mm} / \mathrm{a}$ to 1900 $\mathrm{mm} / \mathrm{a}$ with average of $1400 \mathrm{~mm} / \mathrm{a}$. Based on aridity index of $62.2 \%$ expressed as ratio of annual rainfall to potential evapotranspiration [31], Njoro catchment falls into Agro-climatic zone III that has "medium to high" potential for arable agriculture. The ETo dependence trend with annual rainfall was somehow distinct, with exception of three years (1982, 1984 and 1992) in a span of 17 years. Such dependence characterizes a water stressed region [2]. The finding was in line with reduced infiltration already reported [32] and massive loss of vegetative cover in the area. Ideally, if infiltration and deep percolation of stormwater was taking place sufficiently, then the reduction in forest area would have resulted into the rise of water table in response to reducing ETo. As a result, both interflow and ground water flow would reach the streams and sustain baseflow ensuing a continuous flow throughout the year. This was not the case for Njoro catchment implying that land cover changes had adverse influence on discharge regime. 


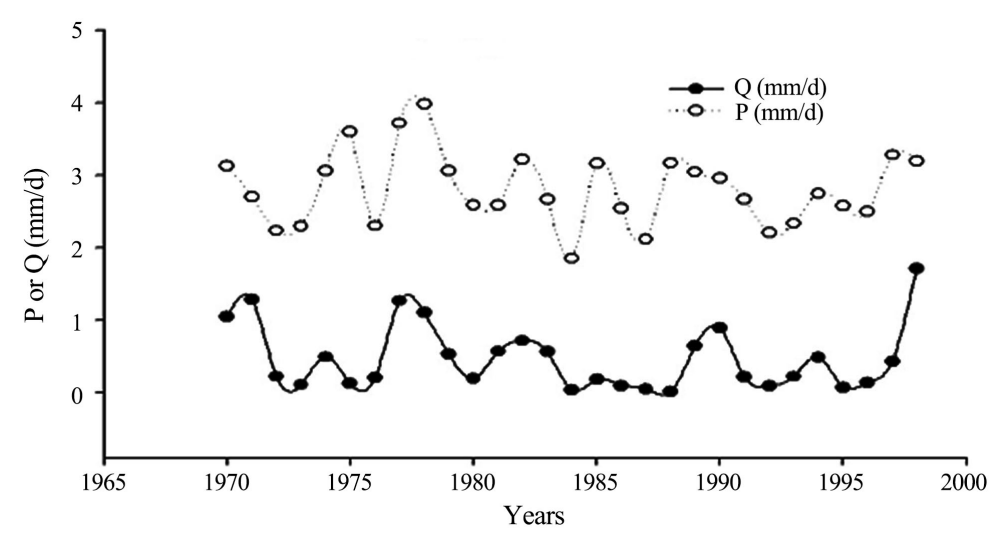

Figure 5. Relationship of annual discharge and rainfall from 1970 to 2000.

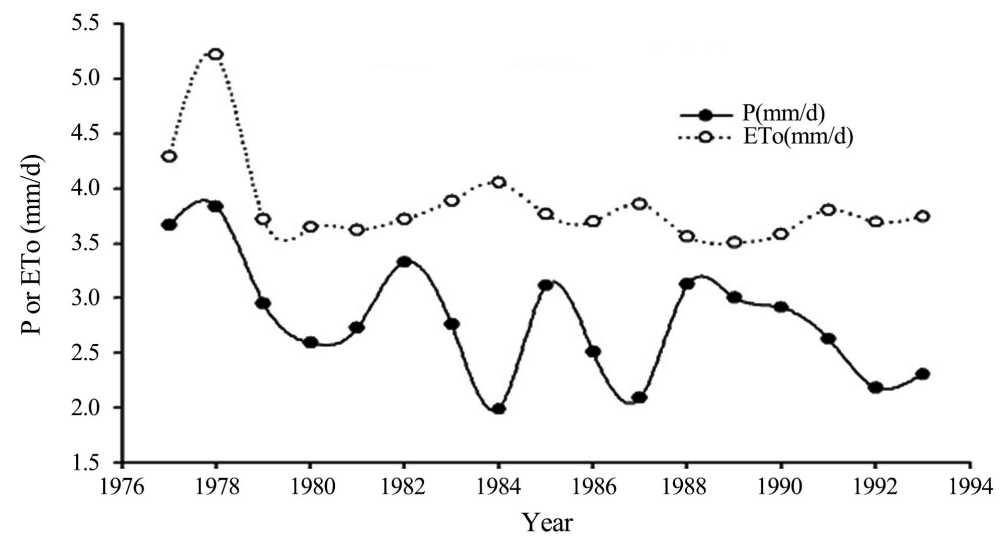

Figure 6. Annual time series of evapotranspiration and rainfall in 1977-1993.

\subsubsection{Analysis of Discharge Response to Land Cover Changes and Climatic Variability}

Figure 7 shows distribution of monthly discharge (Q) for periods I and II at the middle reaches of Njoro River. Discharge in rainy seasons (March-April-May) and highest flow seasons (July-August-September) in Period I remained higher than Period II linked with high changes of land cover. Although studies that relate small scale $\left(<1 \mathrm{~km}^{2}\right)$ changes in land cover with changes in discharge generally indicate that deforestation causes an increase in annual mean discharge, the few studies that evaluated effects of changes in land cover in tropical meso-or large-scale river basins $\left(>100 \mathrm{~km}^{2}\right)$ could not find similar relationships [1] [2] [15]. Therefore, this research finding is in line with these few cases. Annual flow pattern of this river initially dominated by three peaks (May, August and December) seemed to have changed in period II. On annual basis, mean monthly discharges were lowest in January, February and March in period I but this again changed in period II. Lastly, flow pattern declined further in months of November and December in period II an indication of river recession.

Classical statistics (t-test and $\mathrm{z}$-test) were applied to examine difference in means among rainfall, discharge and discharge coefficient in the two periods [1]. Table 5 demonstrates Z-Test for means of long-term rainfall, discharge and dis- 
charge coefficient, and t-test for means of discharge and discharge coefficient for period I and II. Following results were arrived at based on $\mathrm{P}<0.05$ criterion; 1) Monthly means of rainfall are not statistically different and variability in decreases is higher in period I than period II $(4.01>3.06) ; 2)$ Monthly mean of discharge for period II is lower ( $84 \mathrm{~mm} / \mathrm{a}$ or $36 \%$ ) than period I and variability in decreases is higher in period II than period I (5.37 > 4.55); 3) discharge coefficient of period II is greater than period I and variability in decreases is higher in period I than period II. Irrefutably, we can point out that although rainfall did not change significantly between the periods (15\%), discharge and discharge coefficient decreased between the former and latter time periods. Decrease of discharge coefficient indicates that there are major interferences affecting discharge generation after the conversion of forest into open farms and grasslands.

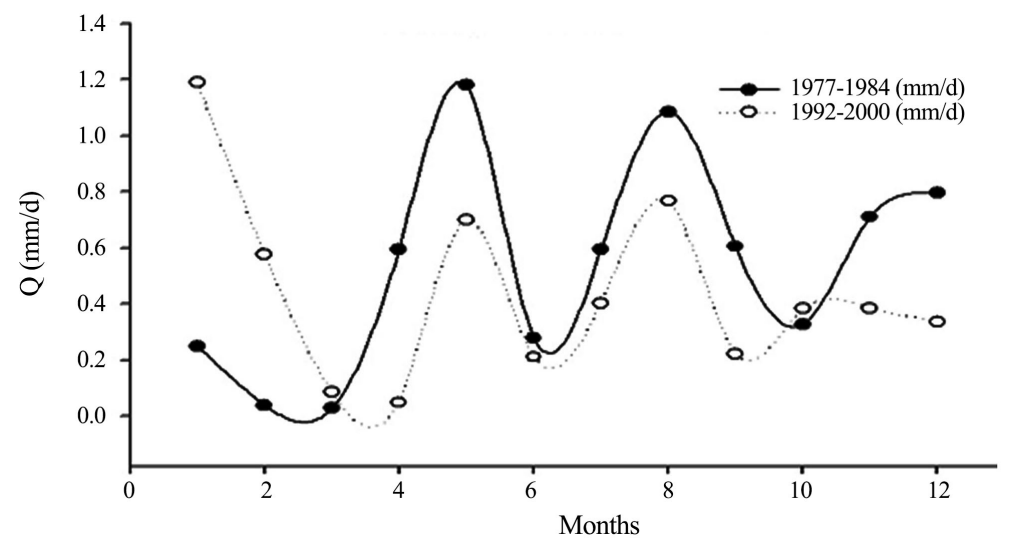

Figure 7. Distribution of monthly discharge (Q) for periods I and II at middle reaches of Njoro River. Period II discharge is consistent with the deforestation trend.

Table 5. Z-Test for means of long-term rainfall, discharge and discharge coefficient, and t-test for means of discharge and discharge coefficient for period I and II.

\begin{tabular}{|c|c|c|c|c|c|c|}
\hline & \multicolumn{2}{|c|}{ Rainfall (mm/month) } & \multicolumn{2}{|c|}{ Discharge $(\mathrm{mm} / \mathrm{month})$} & \multicolumn{2}{|c|}{ Runoff coefficient } \\
\hline & Period I & Period II & Period I & Period II & Period I & Period II \\
\hline Mean & 90.66 & 77.51 & 19.37 & 12.35 & 0.22 & 0.13 \\
\hline Variance & 4492.21 & 2459.49 & & & & \\
\hline SD & 67.02 & 49.59 & 26.68 & 29.13 & 0.31 & 0.22 \\
\hline $\mathrm{N}$ (months) & 96 & & 71 & 71 & 69 & 69 \\
\hline SEM & 6.84 & 5.06 & 3.17 & 3.46 & 0.04 & 0.03 \\
\hline Ho & A & & A & & $\mathrm{R}$ & \\
\hline Df & 95 & & 140 & & 136 & \\
\hline $\mathrm{T}$ statistic & & & 1.4963 & & 2.0530 & \\
\hline $\mathrm{P}(\mathrm{T}<\mathrm{t}) 2$ tail & & & 0.1368 & & 0.0420 & \\
\hline $\mathrm{Z}$ statistic & 4.01 & 3.06 & 4.55 & 5.37 & 4.92 & 4.58 \\
\hline
\end{tabular}

SD: standard deviation; N: number of observations; SEM: standard error mean; Ho: null hypothesis that no mean difference; Df: degrees of freedom; A: Ho accepted; R: Ho rejected at $\mathrm{p}<0.05$. 
Higher decrease in discharge than rainfall trends as shown in Figure 6, especially after 1990 indicates further influence other than rainfall on discharge coefficient. This implies that discharge decreased from the catchment after deforestation. Influence of land cover changes on hydrological processes varies for different places [33]. Streamflow increased due to reforestation in upper-stream area of Yangtze River [34], whereas it increased following deforestation in Loess Plateau area of China [35]. Streamflow decreased under forested areas [36] and baseflow decreased following deforestation [15]. Further baseflow increased following reforestation [37], whereas baseflow decreased following reforestation [38]. These research studies confirm that current finding obtained in this study is in line with others.

Table 6 demonstrates result for paired t-test for means of all rainy seasons, discharge of all high-flow seasons and temperature for period I and II. Paired t-tests for rainy seasons and high flow seasons show that discharge decreased by $51 \%(168 \mathrm{~mm} / \mathrm{a})$ between the two periods with insignificant mean rainfall difference $(\mathrm{p}<0.05)$. Figure 8 shows discharge in four rainy and four dry years in period I and similar years in period II. A considerable reduction of discharge in period II was observed in Figure 8. Although decrease in average annual discharge ( $84 \mathrm{~mm} / \mathrm{a}$ or $0.23 \mathrm{~m}^{3} / \mathrm{s}$ ) could be partially explained by decrease in mean annual rainfall $(15 \%)$ in the same period, the same argument cannot support discharge decrease of $166 \mathrm{~mm} / \mathrm{a}\left(0.48 \mathrm{~m}^{3} / \mathrm{s}\right)$ in rainy season whilst the change in rainfall is not significant $(\mathrm{P}<0.05)$. It implies that despite the fact that soils in the upper catchment were permeable, stormwater did not contribute to both interflow and groundwater flow. That is abstraction and retention of stormwater was not sufficient and reached streams as instantaneous flow. Effects of intense land cover change in another recent study, was evidenced during rainy season by substantially higher discharge than periods of less land cover change [1]. However, similar results could not arrive at Njoro catchment. This is a major finding as the need for appropriate intervention that focuses on improvement of land cover is inevitable.

Increase in temperature of $0.75^{\circ} \mathrm{C}$ from periods I to II was observed that could account for changes in evapotranspiration. In tropical regions, increase in temperature plays an important role in evapotranspiration and soil moisture variation. Subsequently, a significant and subtle increase and decrease in streamflow at different headwaters have been reported when temperature and precipitation increases [39]. Thus, mean temperature difference between the two periods was significant $(\mathrm{P}<0.05)$ and partly contributed to decline of the discharge. Increasing trend in temperature on the catchment has been almost constant for a long time and hence its influence on discharge could be offset by changes in land cover and rainfall [9] [13] [15]. Nevertheless, a research study is recommended at this point to understand how and to what degree do changes in land cover and climate variability in the catchment affect hydrological components (runoff, baseflow, evapotranspiration, lateral flow and streamflow). 

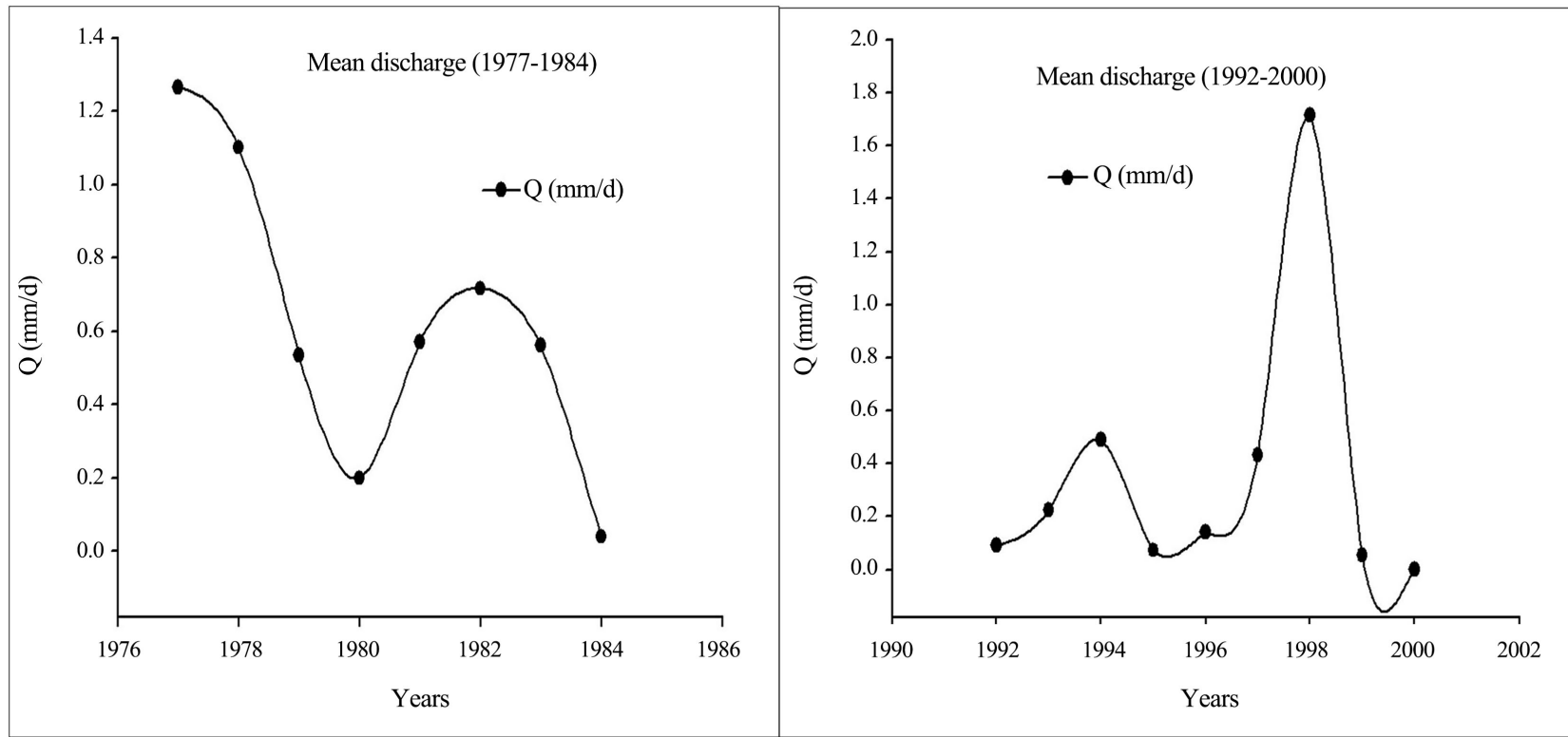

Figure 8. Discharge in four rainy and four dry years in period I and similar years in period II.

Table 6. Paired t-test for means of all rainy seasons (March-April-May) and discharge of all high-flow seasons (July-August-September), and temperature for period I and II.

\begin{tabular}{ccccccc}
\hline & \multicolumn{2}{c}{ Rainfall $(\mathrm{mm} /$ month) } & \multicolumn{2}{c}{ Temperature $\left({ }^{\circ} \mathrm{C}\right)$} & \multicolumn{2}{c}{ Discharge $\left(\mathrm{m}^{3} / \mathrm{s}\right)$} \\
\hline & Period I & Period II & Period I & Period II & Period I & Period II \\
\hline Mean & 119.73 & 84.91 & 18.86 & 19.61 & 0.95 & 0.47 \\
SD & 46.88 & 27.73 & 0.73 & 0.31 & 0.58 & 0.39 \\
N (seasons) & 8 & & 8 & & 7 & \\
SEM & 16.57 & 9.80 & 0.27 & 0.11 & 0.22 & 0.15 \\
Ho & $\mathrm{A}$ & & $\mathrm{R}$ & & $\mathrm{A}$ & \\
Df & 14 & & 7 & & 12 & \\
T statistic & 1.8084 & & 3.0990 & & 1.8158 & \\
$\mathrm{P}(\mathrm{T}<\mathrm{t})$ 2 tail & 0.0921 & & 0.0173 & & 0.0945 & \\
\hline
\end{tabular}

SD: standard deviation; N: number of observations; SEM: standard error mean; Ho: null hypothesis that no mean difference; Df: degrees of freedom; A: Ho accepted; R: Ho rejected at $\mathrm{p}<0.05$.

Table 7 demonstrates Z-statistic and unpaired T-test for discharge variability in 4 rainiest and 4 driest years at $5 \%$ level of significance for period I and period II. Increase in surface flow during rainy season is mainly related to reduced infiltration after changes in land cover [1], whereas reduction on land cover can lead to reduced evapotranspiration and rise of groundwater table [15]. Consequently discharge is influenced by infiltration rate and soil moisture storage capacity [33]. Therefore if land cover changes were responsible for decline in discharge, it is expected that variability in decreases of discharge should be greatest in rainy than dry years. To test this hypothesis, t-test and $\mathrm{z}$-test analysis were carried out for four rainy and four dry years in the two periods. Figure 8 shows discharge in four rainy and four dry years in period I and similar years in period II. The rainy years 
and high flow years in period I were 1977, 1978, 1981 and 1982 while the same for period II were 1993, 1994, 1997 and 1998 (Figure 8). The El Nino effect of 1998 is reflected by exceptionally high peak discharge in that year while La Nina event that followed in 2000 is also captured with exceptionally low flow discharge.

Analysis of discharge in Table 7 demonstrates that; 1) mean discharge in period I was not different at $\mathrm{P}<0.05$ and variability in decreases were higher $(4.60>$ 3.98) in rainy years than dry years, and 2) mean discharge in period II was different at $\mathrm{P}<0.05$ and variability in decreases was higher again in rainy years than dry years $(4.78>4.77)$. This concludes that, land cover changes were responsible for decrease of discharge in Njoro River at $\mathrm{p}<0.05$ level of significance. Analysis of surface hydrological components of the catchment for the two periods considered was of paramount importance in this study. These components are sensitive in altering hydrologic cycle when forests are converted into grasslands or farms in tropical regions [40]. Hydrological sensitivity is usually defined as percentage change in mean annual discharge occurring in response to a change in mean annual rainfall and potential evapotranspiration [1].

Land cover changes and climatic variability bring about perturbations in both rainfall and potential evapotranspiration, which eventually lead to changes in water balance. However, quantification of individual impact is difficult, since most changes in discharge are associated with changes in both climate and human activities [4]. Application of Equations (4) and (5) in NRC, enabled computation of climatic variability influence on mean annual discharge $\left(\Delta Q^{c \text { lim }}\right)$ as $25 \%(0.06$ $\mathrm{m}^{3} / \mathrm{s}$ ) while changes in land cover accounted for $75 \%\left(0.17 \mathrm{~m}^{3} / \mathrm{s}\right)$.

Table 8 demonstrates means of long term hydrological variables in Upper Njoro River Catchment for period I and period. Comparison of hydrological variables between the two periods led to the following observations: 1 ) a decrease in

Table 7. Z-statistic and unpaired T-test for discharge variability in 4 rainiest and 4 driest years at 5\% level of significance for period I (1977-1984) and period II (1992-2000).

\begin{tabular}{ccccc}
\hline & \multicolumn{2}{c}{ Period I, Q $\left(\mathrm{m}^{3} / \mathrm{s}\right)$} & \multicolumn{2}{c}{ Period II, Q $\left(\mathrm{m}^{3} / \mathrm{s}\right)$} \\
\hline Mean & Rainy & Dry & Rainy & Dry \\
Variance & 0.82 & 0.48 & 0.22 & 0.13 \\
SD & 1.05 & 0.53 & 1.19 & 0.02 \\
$\mathrm{~N}$ (months) & 1.02 & 0.73 & 0.31 & 0.22 \\
SEM & 52 & 44 & 60 & 37 \\
Ho & 0.14 & 0.11 & 0.04 & 0.03 \\
Df & $\mathrm{A}$ & & $\mathrm{R}$ & \\
T statistic & 1.8377 & & 95 & \\
$\mathrm{P}(\mathrm{T}<\mathrm{t})$ 2 tail & 0.0693 & & 2.3552 & \\
$\mathrm{Z}$ statistic & 4.60 & 3.98 & 0.0206 & \\
\hline
\end{tabular}

SD: standard deviation; N: number of observations; SEM: standard error mean; Ho: null hypothesis that no mean difference; Df: degrees of freedom; A: Ho accepted; R: Ho rejected at $\mathrm{p}<0.05$. 
Table 8. Means of long term hydrological variables in Upper Njoro River Catchment for period I (1977-1984) and period II (1992-2000).

\begin{tabular}{cccccc}
\hline Period & $\mathrm{P}(\mathrm{mm} / \mathrm{a})$ & $\mathrm{Q}\left(\mathrm{m}^{3} / \mathrm{s}\right)$ & $\mathrm{Q}(\mathrm{mm} / \mathrm{a})$ & $\mathrm{ETo}(\mathrm{mm} / \mathrm{a})$ & $\mathrm{C}$ \\
\hline P1 (1977-1984) & 1048.75 & 0.65 & 228.73 & 821.02 & 0.22 \\
P2 (1992-2000) & 1023.88 & 0.42 & 147.17 & 876.71 & 0.14 \\
\hline
\end{tabular}

P: average annual rainfall from Egerton weather station, Q: mean annual discharge at 2 FC05 gauging station (Egerton), ETo: potential evapotranspiration $(\mathrm{P}-\mathrm{Q})$ and C: discharge coefficient $(\mathrm{Q} / \mathrm{P})$.

annual rainfall in the order of $25 \mathrm{~mm} / \mathrm{a}(2 \%), 2)$ a decrease in discharge of 82 $\mathrm{mm} / \mathrm{a}(36 \%), 3)$ an increase in ETo of $56 \mathrm{~mm} / \mathrm{a}(7 \%)$ and 4$)$ a decrease in discharge coefficient from 0.22 to 0.14 . Of these findings, most critical in hydrological point of view is $36 \%$ decrease in discharge [1]. Decrease in long term discharge and decreased discharge coefficient are all consistent with changes in land cover, although the dynamics of ETo partly lies within uncertainty of rainfall and discharge data. While decrease in discharge can be attributed to decrease in rainfall, increase in ETo in period II can be linked to a mechanism other than climatic variability. In Figure 6, it was shown that ETo had dependence with mean annual rainfall. As a result, decrease in average annual rainfall from period I to II should have yielded a corresponding decrease in ETo. However, this was not the case in the catchment implying other factors that control ETo like vegetation were playing a key role.

\section{Conclusions}

Influence of climatic variability and changes of land cover on discharge regime was examined using components of surface water balance and analysis of land cover changes from 1970 to 2000. The following conclusions can be drawn from this study:

- Forest area in the upper catchment decreased by $25 \%$ while open fields combined with grassland increased by $58 \%$ in the period between 1973 and 2000. Such a decrease in forest cover in a catchment that is about $280 \mathrm{~km}^{2}$ was huge to trigger a remarkable change in discharge regime.

- A significant downward trend was found for average annual discharge, which corresponded with increased reduction in land cover in the upper catchment. The mean annual discharge during period II (1992-2000) was 36\% lower than period I (1977-1984). In the same periods, mean annual temperature increased significantly while rainfall decrease $(24.8 \mathrm{~mm} / \mathrm{a})$ was not significant $(\mathrm{p}<0.05)$. Influence of climatic variability accounted for $25 \%$ while human activities that led to land cover changes accounted for $75 \%$ reduction in annual discharge in period II. Therefore, interventions focusing on reforestation in the catchment are recommended.

- Statistical analysis of four rainy and four dry years in two periods show that; 1) mean discharge in period I (1977-1984) was not different at $P<0.05$ and variability in decreases was higher $(z$-score: $4.60>3.98)$ in the rainy than dry 
years, and 2) mean discharge in period II (1992-2000) was different at $\mathrm{P}<$ 0.05 and variability in decreases was higher again in rainy than dry years (z-score: $4.78>4.77)$. This concludes that, land cover changes were responsible for decrease in discharge in Njoro River at $p<0.05$ level of significance. Consequently, null hypothesis was rejected and alternative hypothesis that states changes in land cover between the two periods were driving influence on discharge was adopted.

\section{Acknowledgements}

Author acknowledges financial support for data collection from Austrian Development Co-operation through the North-South dialogue programme (OEAD), and Kenyatta University for service support during the paper preparation.

\section{Conflicts of Interest}

The author declares no conflicts of interest regarding the publication of this paper.

\section{References}

[1] Marcos, H.C., Aurelie, B. and Jeffrey, A.C. (2003) Effects of Large-Scale Changes in Land Cover on the Discharge of the Tocantins River, Southeastern Amazonia. Journal of Hydrology, 283, 206-217. https://doi.org/10.1016/S0022-1694(03)00267-1

[2] Bruijnzeel, L.A. (1990) Hydrology of Moist Tropical Forests and Effects of Conversion: A State of Knowledge Review. Free University, Amsterdam, 224.

[3] Dyhr-Nielsen, M. (1986) Hydrologic Effects of Deforestation in the Chao Phraya Basin in Thailand. International Symposium on Tropical Forest Hydrology and Application, Chiang Mai, 11-14 June 1986, 16.

[4] Li, L.J., et al. (2007) Assessing the Impact of Climate Variability and Human Activities on Streamflow from the Wuding River Basin in China. Hydrological Processes, 21, 3485-3491. https://doi.org/10.1002/hyp.6485

[5] Mutie, S.M., Mati, B., Home, P., Gadain, H. and Gathenya, J. (2006) Evaluating Land Use Change Effects on River Flow Using USGS Geospatial Stream Flow Model in Mara River Basin, Kenya. Proceedings of the 2 nd Workshop of the EARSeL SIG on Land Use and Land Cover, Bonn, 28-30 September 2006, 141-148.

[6] Maidment, D.R. (1992) Handbook of Hydrology. McGraw-Hill, New York.

[7] Mustafa, Y.M., Amin, M.S.M., Lee, T.S. and Shariff, A.R.M. (2005) Evaluation of Land Development Impact on a Tropical Watershed Hydrology Using Remote Sensing and GIS. Journal of Spatial Hydrology, 5, 16-30.

[8] Ernani, M.Z. and Gabriels, D. (2007) Detection of Land Cover Changes Using Landsat MSS, TM, ETM+ Sensors in Yazd-Aedakan Basin.

[9] Chemelil, M.C. (1995) The Effect of Human Induced Watershed Changes on Stream Flows. PhD Thesis, Loughborough University of Technology, Loughborough.

[10] Mutua, B.M. and Gichaba, C.M. (2006) Effect of Land Use Change on Hydrological Regime in a Rural Catchment: A Case of River Njoro Catchment, Kenya. SOPHYWA, BOKU Vienna, Vienna. 
[11] Yillia, P.T., Kreuzinger, N. and Mathooko, J.M. (2008) The Effects of In-Stream Activities on the Njoro River, Kenya. Part II: Macro-Water Quality. Physics and Chemistry of the Earth, 33, 729-737. https://doi.org/10.1016/j.pce.2008.06.040

[12] Ralph and Helmidt (1984) Agriculture Management Handbook. Ministry of Agriculture and Livestock Development, Nairibi.

[13] Baldyga, T.J. (2005) Assessing Land Cover Change Impacts in Kenya's River Njoro Watershed Using Remote Sensing and Hydrologic Modelling. MSc Thesis, University of Wyoming, Laramie.

[14] Mathooko, J.M. (2001) Disturbance of a Kenyan Rift Valley Stream by the Daily Activities of Local People and Their Livestock. Hydrobiologia, 458, 131-139. https://doi.org/10.1023/A:1013160918203

[15] Kundu, P.M. (2007) Application of Remote Sensing and GIS Techniques to Evaluate the Impact of Land Use and Land Cover Change on Stream Flows: The Case for River Njoro Catchment in Eastern Mau-Kenya. PhD Thesis, Egerton University, Njoro.

[16] Campbell, J.B. (2002) Introduction to Remote Sensing. 3rd Edition, The Guilford Press, New York, 621.

[17] Singh, A. (1987) Spectral Separability of Tropical Forest Classes. International Journal of Remote Sensing, 8, 971-979. https://doi.org/10.1080/01431168708954741

[18] Maingi, J.K. and Marsh, S.E. (2001) Assessment of Environmental Impacts of River Basin Development on the Riverine Forests of Eastern Kenya Using Multi-Temporal Satellite Data. International Journal of Remote Sensing, 22, 2701-2729. https://doi.org/10.1080/01431160010031298

[19] Kenya Forests Working Group (KFWG) (2001) Excision and Settlement in the Mau Forest. Report of Kenya Forest Working Group, 15 p.

[20] Mohamed, A.M. (2006) Catchment Degradation and Impacts on the Hydrology of River Systems in Kenya. WWF, Eastern African Regional Programme Office Report.

[21] Dawes, W.R., Gilfedder, M., Walker, G.R. and Evan, W.R. (2004) Biophysical Modelling of Catchment-Scale Surface Water and Groundwater Response to Land-Use Change. Mathematics and Computers in Simulation, 64, 3-12. https://doi.org/10.1016/S0378-4754(03)00116-2

[22] Milly, P.C.D. and Dunne, K.A. (2002) Macro-Scale Water Fluxes 2. Water and Energy Supply Control of Their Inter-Annual Variability. Water Resources Research, 38, 1206. https://doi.org/10.1029/2001WR000760

[23] Andrew, T.H and Carol, A.W. (2000) Deforestation in Mwanza District, Malawi, from 1981 to 1992, as Determined from Landsat MSS Imagery. Applied Geography, 20, 155-175. https://doi.org/10.1016/S0143-6228(00)00002-3

[24] Jon, E.S., Graeme, L. and Brian, S.H. (2006) Impacts of Land Cover on Stream Hydrology in the West Georgia Piedmont, USA. Journal of Environmental Quality, 35, 2123-2131. https://doi.org/10.2134/jeq2006.0113

[25] Hirsch, R.M., Walker, J.F., Day, J.C. and Kallio, R. (1990) The Influence of Man on Hydrologic Systems. In: Wolman, M.G. and Riggs, H.C., Eds., Surface Water Hydrology, Geological Society of America, Boulder, 329-359. https://doi.org/10.1130/DNAG-GNA-O1.329

[26] Paul, M.L. and Meyer, J.L. (2001) Streams in the Urban Landscape. Annual Review of Ecology and Systematic, 32, 333-365. https://doi.org/10.1146/annurev.ecolsys.32.081501.114040

[27] Congalton, R.G. and Green, K. (1999) Assessing the Accuracy of Remotely Sensed 
Data: Principles and Practices. Lewis Publishers, Boca Raton, 137. https://doi.org/10.1201/9781420048568

[28] WMO (1988) Analyzing Long Time Series of Hydrological Data with Respect to Climatic Variability. Project Description WHO-OD 224 Geneva.

[29] Ojany, F.F. and Ogendo, R.B. (1973) A Study in Physical and Human Geography. Longman, Nairobi.

[30] Mainuri, Z.G. (2005) Land Use Effects on the Spatial Distribution of Soil Aggregate Stability within the River Njoro Watershed, Kenya. MSc. Thesis, Egerton University, Njoro.

[31] Mariara, J.K. and Karanja, F.K. (2007) The Economic Impact of Climate Change on Kenyan Crop Agriculture: A Ricardian Approach. Global and Planetary Change, 57, 319-330. https://doi.org/10.1016/j.gloplacha.2007.01.002

[32] Owido, S.F.O., Chemelil, C.M., Nyawade, F.O. and Obadha, W.O. (2003) Effects of Induced Soil Compaction on Bean (Phaseolus vagaries) Seedling Emergence from a Haplic Phaeozen Soil. Agricultura Tropica et Subtropica, 36, 65-69.

[33] Ma, X., et al. (2009) Response of Hydrological Processes to Land-Cover and Climate Changes in Kejie Watershed, South-West China. Hydrological Processes, 23, 1179-1191.

[34] Cheng, G.W. (1991) An Approach to the Relationship between Runoff Characters and Forest in the Basin of Sichuan. Journal of Soil and Water Conservation, 5, 48-52.

[35] Liu, C.M. and Zhong, J.X. (1978) A Preliminary Study to Relationship between Forest and Annual Runoff in Loess Plateau. Acta Geographica Sinica, 33, 112-116.

[36] Van Lill, W.S., Kruger, F.J. and Van Wyk, D.B. (1980) The Effects of Afforestation with Eucalyptus grandis Hill EX Maiden and Pinus patula Schlecht. Journal of Hydrology, 48, 107-118. https://doi.org/10.1016/0022-1694(80)90069-4

[37] Sandstroem, K. (1995) Forests and Water-Friends of Foes: Hydrological Implication of Deforestation and Land Degradation in Semi-Arid Tanzania. Department Theme Research, University of Linköping, Linköping.

[38] Smith, R.E. and Scott, D.F. (1992) The Effects of Afforestation on Low Flows in Various Regions of South Africa. Water $S A, 18,185-194$.

[39] Chen, Y.N., Takeuchi, K., Xu, C., Chen, Y.P. and Xu, Z.X. (2006) Regional Climate Change and Its Effects on River Runoff in the Tarim Basin, China. Hydrological Processes, 20, 2207-2216. https://doi.org/10.1002/hyp.6200

[40] Costa, M.H. and Foley, J.A. (1997) The Water Balance of the Amazon Basin: Dependence on Vegetation Cover and Canopy Conductance. Journal of Geophysical Research: Atmospheres 102, 23973-23989. https://doi.org/10.1029/97JD01865 